\title{
An Evaluation of the Role of Commercial Banks in Financing Small and Medium Scale Enterprises (SMEs): Evidence from Nigeria
}

\author{
Ibrahim Aliyu Gololo ${ }^{1}$
}

\begin{abstract}
${ }^{1}$ Accounting Department, Faculty of Social and Management Science, Bauchi State University Gadau, Nigeria Correspondence: Accounting Department, Faculty of Social and Management Science, Bauchi State University Gadau, Bauchi, Nigeria, Tel: +234 8036312938, E-mail: aliyugololo2@ gmail.com
\end{abstract}

Received: June 21, 2017

Accepted: July 15, 2017

Online Published: July 20, 2017

\begin{abstract}
In this study an attempt was made to evaluate the role of commercial banks in financing small and medium scale enterprises in Nigeria. There is absolutely no doubt that small and medium scale enterprises play a pivotal role and contributes tremendously to the economic growth and development of many developing economy including Nigeria, but survival of Small and medium scale enterprises is often hampered by access to finance which key players were making attempt to solve. The objective of this study is to evaluate the extent to which commercial banks in Nigeria play their role in solving financing needs of small and medium scale enterprises. The study employed secondary data which use the ratio of loans to Small and Medium Scale Enterprises by commercial banks as a percentage of their total credit for the period between 1991-2012.The study utilize paired sample t-test and significance of ratio of loans to Small and Medium Scale Enterprises was tested to access the performance of Small and Medium Scale Enterprises Equity Investment Scheme by banks to provide finance to Small and Medium Scale Enterprises. The result shows that commercial banks loans even with the equity scheme introduction do not make significance positive impact on loan disbursement to finance SMEs. It is recommended that Nigerian commercial banks should embrace risk-averse behavior in respect of loans to SMEs, interest rate should be review for SMEs loans by Central bank of Nigeria and increase SMEEIS contribution by commercial banks. Specialized bank should be established by government to finance SMEs; it should also provide adequate infrastructural facilities in the country and address present security challenges so as to make Nigeria conducive for SMEs to operate.
\end{abstract}

Keywords: Financing, Nigeria, Small and Medium Enterprises, Small and Medium Enterprises, Equity Investment Scheme, Commercial Banks.

\section{Introduction}

Small and Medium Scale Enterprises (SMEs) are important engines of economic growth, jobs and social cohesion. SMEs play an important role in the economies of many developing countries including Nigeria. Thus, governments throughout the world focus on the development of the SMEs sector to promote economic growth Finlayson, (2003). However, the creation, survival and growth of SMEs are often hampered by access to 
finance. Thus access to SMEs finance has become a key priority in developing countries like Nigeria. Therefore, Non-availability of debt finance to finance operations and expansion is one of the major causes of failure for SMEs in Nigeria. According to Global Entrepreneurship Monitor (GEM) Survey in 2008; financial constraint is the primary exit reason for most SMEs failure in Nigeria. However, the need for SMEs growth in Nigeria is beyond question, but access to finance is a major factor stagnating the way of its growth, as a financing tool, debt financing has a distinct advantages over equity financing for the development of SMEs, but debt financing in Nigeria presently comes with significant challenges as can be seen from low responses of commercial banks to finance SMEs.

There is evidence that most SMEs in Nigeria with low capital formation raise capital through loans from family and friends because at the initial stage, majority of young budding entrepreneurs lack laudable forms of collateral, business plans and feasibility studies to actually meet the requirement and convince banks to grant them loans Ebube, (2011). This implies that a vast majority of SMEs depend on internal finance ( i.e contribution from the owners, family and friends etc). Internal financing is often inadequate for SMEs in Nigeria to survive and grow, as it is increasingly difficult to keep the costs within the constraints of self-financing. Therefore SMEs need capital from external sources (or Debt Financing). Because of this Nigerian Government over time introduced Small and Medium Enterprises Equity Investment scheme (SMEEIs) as an initiatives through Commercial banks by the CBN to solve financing problem of SMEs and the creation of (Small and Medium Enterprises Development Agency of Nigeria) SMEDAN as an agency to enhance the development of SMEs.

The Banking System is very important for any nation because it is the pivot of socio-economic development of any economy Terungwa, (2011). This implies that commercial banks have active developmental roles to play in the economy such as mobilizing fund from the surplus to the deficit spending units. Commercial banks are considering as the main source of finance for SMEs or rather entrepreneurs in Nigeria. Akabueze, (2002) assert that Finance has been seen as a critical element in the growth and development of SMEs. For instance the commencement and efficient performance of any industrial enterprises be it small or large will require the provision of funds for its capitalization, working capital and rehabilitation needs, as well as for the creation of new investments. Provision of funds to the industrial sector, particularly, for the SMEs has, therefore, been of prime interest to policy-makers in both the public and private sectors. It is a known fact that firms depend on a variety of sources for their finances. These include external and internal, formal and informal sources Aruwa 2004. According to Demirguc-Kunt, Maksimovic, Beck and Laeven, (2006) External finance makes many SMEs developed, they depends on bank loans and overdrafts and suppliers credit for early stage financing. Despite the dependence of SMEs on debt finance, paradoxically access to debt finance is very limited for SMEs in Nigeria. Mambula (2002) laments that Small and medium scale enterprises dominate the private sector of the Nigerian economy, but almost all of them lack access to credit finance. This implies that Commercial banks and trade creditors hesitate to lend to SMEs. However, only few SMEs in Nigeria are able to access bank loans. Previous studies have decried the limited access to external financial resources available to smaller enterprises compared to larger organizations and the consequences for their growth and development (Hossain, 1998; Wattanpruttipaisan, 2003; Berger and Udell, 2004; Ogujiuba et al., 2004 ;).

According to Velverde et al (2005) bank credit play a crucial role in providing for external financing to SMEs, but in Nigerian context, this crucial source of finance for SMEs is apparently non-functional Kadiri, (2012). 
An Evaluation of the Role of Commercial Banks in Financing Small and Medium Enterprises (SMEs): Evidence from Nigeria

This is evident in the ratio of loans to SMEs to Commercial banks' total credit, which shows that a meager $0.13 \%$ of commercial banks' total credit was granted to SMEs in the year 2012 (CBN 2012). More worrisome is the fact that this ratio has been falling over the years Iorpev, (2012). On the other hand, internal sources include personal savings, loans from family and friends, retained earnings and disposal of the enterprise assets and Esusu Contribution.

The Main objective of this study is therefore to evaluate the extent to which commercial banks in Nigeria play their role in solving financing needs of Small and Medium Scale Enterprises (SMEs). In view of this, this study specifically intends

- To highlight the different sources of finance available to small and medium scale enterprises in Nigeria.

- To identify the problems encountered by small scale industrialists in obtaining finance from Nigerian commercial banks.

- To proper possible solutions to financing problems of small and medium scale enterprises in Nigeria.

In line with the objectives, null hypothesis is formulated.

- Ho: Commercial banks loans granted to SMEs have no any significant impact on their development in Nigeria before and after SMEEIS introduction.

\section{Review of Literature}

\subsection{Overview of Small and Medium Scale Enterprises}

Because of the pivotal role that small and medium scale enterprises play in the economy of many countries, different countries of the world defined SMEs in different ways but all the definitions shared common things such as number of employees and total assets base. In Nigeria, however, the definition was not different. SME was defined by the national council on industries in July, 2001 according to size and scale of operations.

\subsubsection{Small Scale Industry}

An industry with a labour size of 11-100 workers or a total cost of not more thanN50 million, including working capital but excluding cost of land.

\subsubsection{Medium Scale Industry}

An industry with a labour size of between 101-300 workers or a total cost of over N50 million but not more than N200 million, including working capital but excluding cost of land.

In essence, SMEs are defined as an enterprises with a maximum total cost of N200 million including working capital but excluding cost of land, and with the number of staff employed by the enterprise not less than 11 and not more than 300. On the other hand, the revised Operational Guidelines of Small and Medium Enterprises Equity Investment Scheme SMEEIS (2006) defines a small and medium enterprise as an enterprise with a maximum assets base of one billion five hundred million naira (N1.5b)(excluding land and working capital), and with no lower or upper limit of staff. Moreover, Nigerian government should as a matter of fact review the above definition every five (5) years as given by the national council on industry because in present day SMEs should possess more than N1.5 billion naira working capital since the definition was derived 6 years ago to meet up with the present Nigerian economic realities.

\subsection{Characteristics of Small and Medium Scale Enterprise in Nigeria.}

The Small and Medium Scale Enterprises (SMEs) in Nigeria are commonly characterized by the following: 
- Simple management structure resulting from the fusion of ownership and management by one person or very few individuals.

- SMEs tend to strongly revolve around the owner-managers, rather than as a separate corporate entity.

- There is often greater subjectivity in decision making and prevalence of largely informal employer employee relationships.

- Many SMEs are labour-intensive although modern SMEs are increasingly employing reasonably high technology.

- Personal commitment of the proprietors whose life savings usually form the start-up capital

- Ease of entry and exit

- High potential for employment opportunities.

- The manager performs all functions of management himself that is he/she handles financial, production, marketing and personnel decision of the enterprise.

- The manager finds it difficult to borrow short and long term finance from organized financial institutions and therefore rely so much on personal savings, relations, money lenders or profit of the enterprise for finance.

- The business enterprises cater or meet only the immediate demands of the local community where the business is carried out without knowledge of wider coverage or distant markets.

- The managers are usually conservative and suspicious and Unwillingly to divulge information regarding their business for fear of inviting unwelcome tax investigations.

- Low level of management skills, poor marketing information and technical condition of production due to low level of education among managers weaken their establishment and also the proprietors are reluctant to combine in partnership or limited liability companies due to mutual distrust. All these lead to high mortality rate among them.

- Little or no proper accounting record keeping and this adversely affect their access to utilize banking services example loan facility.

\subsection{Role/Benefits of Small and Medium Scale Enterprises in the Nigerian Economy}

In Nigeria every known regime recognizes the importance of promoting SMEs as the basis of economic growth and sustainable development. In a developing economy like Nigeria, the commitment to the development of SMEs is an effort towards the development of the whole economy. Kpelai, (2009) as cited in Terungwa, (2011) asserts that SMEs are the engine room for the growth of any developing economy, because they form the bulk of business activities in developed and developing economies like Nigeria. According to (Udechukwu; 2003; Ayesha; 2007; Ayozie and Latinwo 2010; Sirifiyu and Njogo; 2012) SMEs encourage entrepreneurship development and employment generation. On the other hand, Salami, (2003) view SMEs benefit as accelerating the achievement of wider economic and socio-economic objectives, includes poverty alleviation. The potential benefits of SMEs to any economy include contribution to the economy in terms of output of goods and services; creation of jobs; provision of a vehicle for reducing income disparities; development of a pool of skilled and semi-skilled workers as a basis for future industrial expansion, among others.

According to Philip, (1989) at a national conference on small and medium scale enterprises development held at Ibadan "small scale enterprises are said to be bedrock of any national industrial development especially in a typical developing country like ours." The role small and medium scale enterprises play in a developing 
economy is so vast and enormous that they cannot ordinarily be neglected. This was noticed in countries like India, Pakistan, Indonesia, Bangladesh, Japan, China, U.S.A, Taiwan and South Korea to mention just a few, where small and medium scale enterprises (SMEs) contributes in the agro-based sub-sector, textile manufacturing, leather and leather products sub-sector etc. In some of these countries, small and medium scale enterprises are funded and operated by single family employing more than 60 percent of the population. The role and importance of these firms according to Philip, in any nation are as follows:

- They Form Starting Point For Industrialization Which Calls For The Establishment Of Industries Of All Types And Sizes: for instance, Microsoft company may be a software giant today, but it started off in typical SME fashion, as a dream developed by a young student with the help of family and friends, Bill Gates were able to take it to the market place where it is today.

- Small And Medium Scale Enterprises Provide Employment Opportunity Per Unit Of Capital Invested Because They Are Generally Labour-Intensive: Globally, employment generation is one of the most important reasons for promoting the development of SMEs. This more so in the developing countries in which a large proportion of the labour force is unemployed. many countries benefits from employment of small and medium scale enterprises, ranging from 45 per cent (manufacturing sector only in Australia to 79.3 per cent in Switzerland (World Bank, 2008) In addition, the study showed that recent gains in employment in the US, U.K., Germany and Spain were almost confined to small firms, employing fewer than $20 \%$ workers (World Bank, 2008). In Nigeria, the small and medium scale enterprises sub-sector has been expanding, especially since the mid-1980s, following the prolonged recession in the economy which forced many large enterprises to lay off large proportions of their workforce. The sector accounts for about 70 per cent of industrial employment (World Bank, 1995). Also, the agricultural sector, which largely consists of SMEs, employs over 60 per cent of the nation's work force.

- They Aid Large-Scale Industries by Manufacturing Raw Material Inputs and Generally Acts as a Catalyst to Them, And Helps Expand the Nation Output Thereby Generating the Desire to Build a Healthy Industry Base: In many middle-income economies small and medium scale enterprises contribute substantially to the national output. In India for example, the small scale industry sub-sector alone, excluding medium enterprise, accounted for 40 per cent of total industrial output and 35 per cent of total exports in 1998. The sub-sector produces over 75,000 products (India, 2000). In Nigeria, however, the output of the sector is low. Although the SME sector as a whole account for about 70 per cent of total industrial employment, its contribution to manufacturing output is estimated at only 10-15 per cent, indicating very low contribution.(CBN, 2010)

- They Are Often The Sources Of New Ideas And Invention That Is, They Help To Form Technological Base Where They Start Operating As Small Unit Innovating Indigenous Goods And Services To Suit Our Particular Needs Using Local Resources, Product, Equipment And Manpower: All economies have transited from household artisan industries over time to the modern industrial set-up which has witnessed phenomenal upgrading in skills, machinery and equipment, and management practices. Historical evidence indicates that most of today's giant corporations began as very small firms. These include Guinness of Dublin and Philips international of the Netherlands; as well as Sonny and Honda of Japan. Developing countries can learn from the experience of these giants and create a conducive environment that will enable 
small and medium scale enterprises to adapt imported technologies, modernize their process and grow to become large corporation.

- Promotion of Even Development and Reduction of Income Disparities: The promotion of SMEs development aids the dispersal and diversification of economic activities, and induces even development in a country or region. This is because SMEs need relative small seed capital to start operations and their raw materials are widely dispersed in most countries. In addition, their processing technologies and management styles are simple, making investment in the sector affordable to the ordinary people in the society.

- They Generally Source Their Raw Materials Locally Thereby Conserving Foreign Exchange: Small and medium scale Enterprises (SMEs) are known for their creativity in the utilization of local raw materials, that do not require high level technology to process. In Nigeria for instance, SMEs are concentrated in such enterprises as food processing, textiles, wood works, leather products, soap and detergent sub-sector etc that require simple technology and the raw material are in abundance. The enterprises also recycle discarded by-products of large firms as primary inputs in their own production processes.

- They Are Less Vulnerable In Period Of Depression And This Have Greater Degree Of Flexibility Than Large Scale Industries: This is due to the fact of smaller unit of operation because most of them are sole proprietorship and the manager or proprietor controls all the enterprise activities.

- Their Establishment Provides An Increase In The Revenue To The State And Local Government Areas Which May Be Used To Provide Social Amenities: Through various forms of taxes, including personal and company income taxes, SMEs contribute to increasing government revenues in Nigeria.

- Presently in Nigeria, the small and medium scale enterprises contributes immensely to the Nigerian economic growth and development, because the sub-sector employed a large number of Nigerian citizens and this made them to utilized local raw materials in their production process. The Nigerian government having realized the importance of SMEs has since developed financing avenues to help cater to their financing needs so as to keep them liquid however the policy implementation of this financing need is a matter of great concern to researchers, practitioners and even policy makers.

\subsection{Financing Problems of Small and Medium Scale Enterprises (SMEs) in Nigeria}

The problem of SMEs financing received tremendous research efforts from researchers. Some notable works in this respect include Aernold (1998), Anic and Paus (1998), Inang and Ukpong (2002) and Aruwa (2004). In their findings, five problems in financing SMEs have become recurrent: the cost of capital; credit risk; the inappropriate terms on bank loans; difficulty in accessing loans; and the shortage of equity capital. Another scholar identified financing as a key managerial problems confronting SMEs in Nigeria today Terungwa (2011). According to Udechukwu and Olorunshola (2003) Small and Medium Scale Enterprises are bedeviled with the following problems which result for their failure.

- Lack of proper and accurate accounting records keeping that will actually give reliable financial state of affairs of the enterprise.

- Non- segregation of personal assets from that of company by entrepreneurs thereby making the valuation of the business difficult.

- Fear of dominance or hijacking by banks thus making the promoters to resist dilution of control. 
- In ability of the entrepreneurs to provide timely and accurate information/documents that will facilitate the processing of their loan request.

- Absence of good corporate governance on the part of SMEs management.

- Low capital base of the enterprise

- Inadequate and inefficient infrastructural facilities which tend to escalate costs of operation, as SMEs are forced to resort to private provisioning of utilities such as road, water electricity, etc.

- Lack of adequate credit facility for SMEs, traceable to the reluctance of banks to extend credit to them owing, among others, to poor documentation at project proposals as well as inadequate collateral by SME operators.

- Bureaucratic bottlenecks and inefficiency in the administration of incentives which discourage rather than promote SME growth.

- Weak demand for products, arising from low and dwindling consumer purchasing power and lack of patronage for locally produced goods by those in authority.

- Incidence of multiplicity of regulatory agencies and taxes which has always resulted in high cost of doing business and poor management practices and low entrepreneurial skill arising from inadequate educational and technical background of many SME promoters.

- Financial Indiscipline; Some SME proprietors deliberately divert loans obtained for project support to ostentatious expenditure. Some do not divert, but refuse to pay back as and when due, the interest and the principal.

- Poor Implementation of Policies; The poor implementation of policies, including administration of incentives and measures aimed at facilitating SMEs growth and development have had unintended effects on the sub-sector.

- Overbearing Regulatory and Operational Environment;The plethora of regulatory agencies, multiple taxes, cumbersome importation procedure and high port charges has continued to exert serious burden on the operations of the SMEs. Many SMEs have to deal with myriad of agencies at great cost.

- Problems and costs of business registration, land acquisition and other peculiar problems

- High rate of business failures due to state of Nigerian economy;

- Attitudinal disposition of Nigerians toward made-in- Nigeria goods; i.e lack of patronage of made in Nigerian goods, hence this result from most Promoters of SMEs low educational background, lack of management and entrepreneurial skills.

The availability of and accessibility to credit is also crucial to the effectiveness of SMEs in Nigeria. For local people to generate income from productive activities requires credit, especially to stimulate traditional heavily under-capitalized local enterprises. Availability of credit, more than any other service, awakens the aspirations of potential entrepreneurs. The frequent changes, and sometimes conflicting government monetary policies, have also tended to hurt the SMEs. For example, while the government increased total credit allocation to SMEs from 10 to 20 per cent, the same government removed excess liquidity in the banking industry through increases in the minimum rediscount rate (MRR), transfer of government and parastatals accounts to the Central Bank and the creation of a stabilization securities account (SSA) whereby the banks were debited with excess liquidity in their accounts with the Central Bank of Nigeria. 
An Evaluation of the Role of Commercial Banks in Financing Small and Medium Enterprises (SMEs): Evidence from Nigeria

Ibrahim Aliyu Gololo

\subsection{Solutions to Financing Problems of Small and Medium Scale Enterprises in Nigeria.}

The following solutions are therefore offered to remedy some of the problems of small and medium scale enterprises in Nigeria.

- Changing the mindset of bank staff to offer more attractive loan facility to small and medium scale enterprises sub-sector.

- Changing the mindset of Nigerian consumers to patronize made in Nigerian goods so as to encourage the producers of those SMEs products.

- Training and re-training of Nigerian entrepreneurs to acquaint them with the modern technological production process; this, of course can be organized by the private sector or government to help improve their technological know-how.

- Nigerian entrepreneurs must be ready to show greater desire to institutionalize and separate the company from self.

- Continuous enlightenment campaign by the central bank of Nigeria and the banking industry for the importance of the SMEs sub- sector

- Government must ensure stable economic and interest rate policy and so also stable political environment for the entrepreneurs to operate.

- Government also must ensure a conducive environment by providing infrastructures, capacity building, regulatory and legal framework for the enterprises.

- Small and medium scale enterprises should not be subjected to multiple taxes as this discourages them from going on with the business.

- Entrepreneurs should inculcate financial indiscipline in their enterprises

- Sufficient credit facility should be made available by commercial banks to SMEs to cushion the effect of starting business with low capital base.

\subsection{Sources of Small and Medium Scale Enterprises Financing in Nigeria}

The importance of finance to business organization cannot be over-emphasized. Business finance is however, not easy to come by especially in respect of SMEs. SMEs require funds from every source available to meet their asset needs, working capital needs, and for expansion purpose. Nnanna (2001) observes that the bank loan (credit) is important for the take-off and efficient performance of any enterprise. Such an enterprise may be small, medium or large. Loan is the formal source of financing SMEs and it is the largest element of risk in the books of most commercial banks in Nigeria and failures in the management of credit risk mostly weakens individual banks and in some cases, the banking system as a whole, has contributed to many episodes of financial instability. The banks by their nature and position in the economy remain the known formal source of finance for enterprises (Agumagu, 2006). It is disheartening to know that a 2001 World Bank survey on Nigerian firms showed that although $85 \%$ of the firms had relationships with banks, but, most of them had no access to their credit. This explains why SMEs in Nigeria represent about $80 \%$ of firms in the Nigerian industrial sector on numerical basis but regrettably contribute as low as 10\% to GDP in contrast to countries like Indonesia, Thailand and India where SMEs contribute almost $40 \%$ to GDP (WEACI, 2002). Aladekomo (2003) notes that successive governments in Nigeria have, since the last three decades, shown great interest in financing of SMEs, by establishing specialized banks and other credit agencies/schemes to provide customized funding to the sub-sector to enhance growth and stability. In addition to these, programmes like the Nigerian 
An Evaluation of the Role of Commercial Banks in Financing Small and Medium Enterprises (SMEs): Evidence from Nigeria

Ibrahim Aliyu Gololo

Directorate of Employment (NDE), Better Life for Rural Women, Family Support Programme, Child Care Trust, Peoplees Bank, National Poverty Eradication Programme (NAPEP), have been founded to support SMEs in Nigeria. Therefore, in this studied two different sources of financing SMEs have been identified namely: internal and external sources.

\subsubsection{Internal Sources}

\subsubsection{Owner's Savings}

Owner's savings or Personal savings: this simply means funds save over time by the entrepreneur with the intention of financing the business it mostly forms the initial source of funds for the take-up of small and medium scale business in Nigeria. It is very cheap source of fund when business commence operations, however, the expansion will depend on increase in owner's savings. When this source is depended upon, and limited rate of expansion will be experienced.

\subsubsection{Retained Earnings}

This is defined as "undistributable profit of the company which is plough back to the enterprise for expansion." The entrepreneur will therefore wish to maximize the value of his consumption overtime and in terms of cash. In order to do this, he may wish to differ the consumption of part of his income or wealth in order to be in a position to consume more at a later date, or may wish to spend more than he has now anticipating future income or wealth by borrowing on the strength of what he has. When part of profit is not used or is reserved. The enterprise always resorts to it when the need for finance arises.

\subsubsection{Disposal of Asset}

Assets are disposed when they become obsolete and this is a source of fund to the organization. Also surplus asset, represent a once-off (overtime) internal sources of fund which becomes available from time to time. Examples of assets disposed are outright sales of building, plant, machinery and equipment, or other investments.

\subsubsection{Depreciation}

It is a reserve of costless source. It is another cheap source of fund to small and medium scale enterprises in Nigeria. It is a secret reserve because when it is charged to profit and loss as an expensed, no actual cash movement out of the business is involved. It can also be defined as part of the cost of asset consumed during its period of use by the organization.

\subsubsection{Loans from relatives and friends}

Majority of entrepreneurs in Nigeria are having difficulty in raising funds through commercial banks, due to difficulty and non-availability of loans. This makes most of them to raise funds through family and friends.

\subsubsection{Esusu contribution}

Esusu is a name given by the Yorubas of Nigeria to a particular type of informal credit institution organized and operated mainly by farmers, petty traders, craftspeople, social clubs, teachers, civil servants, etc. It is a major and popular form of informal financial institution which is identified across Africa. It is also called Susu, adashi, sanduk, tontines and hangbad in Ghana, Chad, Sudan, Cameroon and Somalia, respectively. The Esusu arrangement is helpful in business finance as it provides members or contributors with a lump sum that can be employed in their business.

Most small and medium scale enterprises sticked to internal sources because they are good for planning, flexibility, no encumbrances attached, less bureaucracy involved, from risk of relaying on external sources. 
An Evaluation of the Role of Commercial Banks in Financing Small and Medium Enterprises (SMEs): Evidence from Nigeria

However, if additional financing is required.There is often an irresistible desire to look outside the firm immediately. But internal sources should be considered especially to small and medium scale enterprises because they are normally cheaper than external sources. In addition, financing from within provides the opportunity to redeploy existing funds so as to achieve a more efficient utilization of capital

\subsubsection{External Sources}

\subsubsection{Commercial Banks Loans}

The commercial banks in Nigeria provide assistance in form of loans to small and medium scale enterprises under the umbrella of small and medium scale enterprises equity investment scheme (SMEEIS) where they contribute parts of their profit before tax to finance SMEs development in Nigeria. The potential entrepreneurs are therefore expected to benefit from these loans given by the commercial banks. However, banks have been very reluctant to grant loans to SMEs, which they regard as a high-risk sub-sector. Most of the banks would rather pay the penalty imposed for not meeting the minimum exposure to preferred sectors of the economy than actually run the risk of being exposed to them. Over the years, Nigerian commercial banks have variety of credit facilities for the SMEs finance and these includes working capital finance (overdraft), import finance facility, equity finance, short-term loans and long-term loans. These credit facilities cut-across almost all the banks. An entrepreneur can access any of the facility when meet the requirement of the banks. The banks also have launched a number of initiatives to serve the SMEs sub-sector better. These are:

- Reducing costs of lending by applying latest information technologies, streamlining the organization and simplifying the lending process.

- Developing products better adapted to SMEs needs

- Improving financial services for SMEs through training of banks staff and segmentation of SMEs customers.

- Reducing information asymmetry of SMEs and high perceived risks by using credit scoring system.

- Simplifying strict rules of lending policy of the banks.

Table 1: Showing Commercial Banks Loans To SMEs from Year 1991-2012

\begin{tabular}{lllll}
\hline Years & $\begin{array}{l}\text { Commerci } \\
\text { al Banks } \\
\text { Loans To } \\
\text { Smes (N' } \\
\text { Million) }\end{array}$ & $\begin{array}{l}\text { Commercial } \\
\text { Banks Total } \\
\text { Credit } \\
\text { (N'million) }\end{array}$ & $\begin{array}{l}\text { Commercial } \\
\text { Banks Loans To } \\
\text { Smes As } \\
\text { Percentage Of } \\
\text { Total Credit }\end{array}$ & $\begin{array}{l}\text { Commercial Banks Loans } \\
\text { Percentage } \\
\text { (Increase/Decrease) After } \\
\text { Smeeis Introduction By Banks }\end{array}$ \\
\hline 1991 & $32,912.40$ & $7,572.30$ & 23.80 & ---- \\
\hline 1992 & $20,400.00$ & $41,810.00$ & 48.80 & ---- \\
\hline 1993 & $15,462.90$ & $48,056.00$ & 32.20 & ---- \\
\hline 1994 & $20,552.50$ & $92,624.00$ & 22.20 & ---- \\
\hline 1995 & $32,374.50$ & $141,146.00$ & 22.90 & ---- \\
\hline 1996 & $42,302.10$ & $169,242.00$ & 25.00 & ---- \\
\hline 1998 & $40,844.30$ & $240,782.00$ & 17.00 & ---- \\
\hline
\end{tabular}


An Evaluation of the Role of Commercial Banks in Financing Small and Medium Enterprises (SMEs): Evidence from Nigeria

Ibrahim Aliyu Gololo

\begin{tabular}{|c|c|c|c|c|c|}
\hline 1999 & $46,824.00$ & $353,081.00$ & 13.30 & ----- & \\
\hline 2000 & $44,542.30$ & $508,302.20$ & 8.80 & ----- & \\
\hline 2001 & $52,428.40$ & $796,164.80$ & 6.60 & 2.2 & I \\
\hline 2002 & $82,368.40$ & $954,628.80$ & 8.60 & 2 & $\square$ \\
\hline 2003 & $90,176.50$ & $1,210,033.10$ & 7.50 & 1.1 & $\sqrt{ }$ \\
\hline 2004 & $54,981.20$ & $1,519,242.70$ & 3.60 & 3.9 & I \\
\hline 2005 & $50,672.60$ & $1,899,346.40$ & 2.70 & 0.9 & $\sqrt{2}$ \\
\hline 2006 & $25,713.70$ & $2,609,289.40$ & 1.0 & 1.7 & ת \\
\hline 2007 & $41,100.40$ & $4,820,695.70$ & 0.9 & 0.1 & ת \\
\hline 2008 & $13,512.20$ & $7,799,400.10$ & 0.2 & 0.7 & Ш \\
\hline 2009 & $16,366.50$ & $9,667,876.70$ & 0.17 & 0.15 & 几 \\
\hline 2010 & $12,550.30$ & $9,198,173.10$ & 0.14 & 0.3 & 介 \\
\hline 2011 & $15,611.70$ & $9,614,445.80$ & 0.16 & 0.2 & $\sqrt{3}$ \\
\hline 2012 & $13,863.5$ & $10,440,956.30$ & 0.13 & 0.3 & \{1 \\
\hline
\end{tabular}

Source: Central Bank of Nigeria Statistical Bulletin (December 2012)

In table 1 above, it appears obviously there are fluctuations in the equity financing of SMEs by commercial banks twelve years after the introduction of SMEEIS by commercial banks to support SMEs financing. Only in year 2004 the banks were able to record highest increment of 3.9\%. In essence the ratio of commercial bank loans to SMEs continued to decline even with the SMEEIS put in place, this is due to the stringent conditions for accessing finance under SMEEIS and non-enforcement of sanctions to erring banks whose fail to adhered completely to SMEs financing. Though some commercial Banks claims non-compliance to support SMEs rising from shortage of skill among the sponsor of the SMEs, weak infrastructural facilities, high administrative costs to monitor loans advanced to the SMEs, poor demand for the finished products of the SMEs, restricted access and land tenure system in operation in the country, difficulties in input procurement and lack of continuity after the death of their owners, notwithstanding, they should mitigate these risks and ensure steady flow of loans to SMEs.

\subsubsection{Development Banks}

Small and medium scale enterprises also obtain financial assistance from development banks and micro-lending institutions such as The Nigerian Industrial Development Bank (NIDB), Bank of Industry (BOI) the people's Bank of Nigeria (PBN), community Banks (CB), Nigerian Export and Import Bank (NEXIM), Nigerian Agricultural, Cooperative and Rural Development Bank (NACRDB) and Bank of Agriculture (BOA). This is done to further ensure that SMEs sector is developed, government in its effort encourage these institutions to lend to SMEs sector, most of these development banks have contributed by setting aside billions of naira for SMEs finance.

\subsubsection{Trade Credit}

Trade Credit refers to transactions which allows for the cash settlement to be done at a different period. It is based on conditions called credit terms which include the credit period, the size of the cash discount, and the discounting cash period. 
An Evaluation of the Role of Commercial Banks in Financing Small and Medium Enterprises (SMEs): Evidence from Nigeria

Ibrahim Aliyu Gololo

\subsubsection{Hire Purchase}

Hire Purchase is a financial arrangement between a hire-purchase company (hirer) and its customers whereby the later (hiree) is allowed to take possession of equipment or goods without immediate cash payment. The legal title of the equipment remains with the owner until the hiree exercises his right of option to purchase, and then the ownership passes to him.

\subsubsection{Equipment Leasing}

In this system, the enterprise instead of buying and owning assets, it enters into an agreement with a leasing firm whereby the borrower is allowed to use the assets on terms of leasing for a specified period of time. This form of short-term finance offers opportunity to small and medium scale enterprises to get a required equipment for their production without being purchased.

\subsection{Review of Related Previous Studies}

A review conducted of some foreign studied on financing small and medium scale enterprises shows that countries like Canada, Japan, U.S.A, China, India, South Africa and some European Union countries approach SMEs financing with the indispensible support of banks loans and other financial institutions, In some of these countries the government and financial institutions "share the risks inherent in extending credit" in which SMEs financing comes in form of bank loans with low interest rate, credit guarantees, loans/equity investments and grants. However, findings from few studied carried out in Nigeria were that, among the most popular of the formal sources of financing, the commercial banks and development banks supposedly remain the readily available source of financing option for enterprises (Aruwa; 2004 Terungwa; 2011 Garba; 2005 Kadiri 2012).

\section{Research Methodology}

In this research work, the methodology is geared towards studying the financing of small and medium scale enterprises by Commercial Banks in Nigeria using their ratio of loans disbursed to SMEs. The study employs both survey research design and empirical method which utilize existing records and documents that relate to the subject under study. Therefore, the study intends to look at the lending habit of commercial banks to SMEs and how it affects SMEs from 1991-2012 that is Ten Years before the introduction of SMEEIS and Twelve Years after the SMEEIS introduction by the banks in Nigeria. To achieve this, paired sample t-test was used. The t-test is used to measure the significance of loans to SMEs by banks who contribute to the SMEEIS funds. The banks loans to SMEs as a percentage of its total credit from 1991-2000 was taken as a separate pair which relate to the period when SMEEIS was yet to be introduce. Bank loans to SMEs as a percentage of its total credit for the period 2001-2012 was taken as the second pair which now relates to the period SMEEIS was introduced. The paired sample t-test was then statistically applied to see if there is any significance in the disbursement of loans to SMEs between these periods.

\section{Data Presentation, Analysis and Discussion of Result}

Table 2: Computation of paired sample t-test

\begin{tabular}{lllll}
\hline Years & $\mathbf{X}$ & $\mathbf{Y}$ & $\mathbf{d}=(\mathbf{x}-\mathbf{y})$ & $\mathbf{d}^{2}$ \\
\hline $1991 / 2001$ & 23.80 & 6.60 & 17.2 & 295.84 \\
\hline $1992 / 2002$ & 48.80 & 8.60 & 40.2 & 1616.04 \\
\hline $1993 / 2003$ & 32.20 & 7.50 & 24.7 & 610.09 \\
\hline $1994 / 2004$ & 22.20 & 3.60 & 18.60 & 345.96 \\
\hline
\end{tabular}


An Evaluation of the Role of Commercial Banks in Financing Small and Medium Enterprises (SMEs): Evidence from Nigeria

Ibrahim Aliyu Gololo

\begin{tabular}{lllll}
\hline $1995 / 2005$ & 22.90 & 2.70 & 20.20 & 408.04 \\
\hline $1996 / 2006$ & 25.00 & 1.0 & 24.00 & 576.00 \\
\hline $1997 / 2007$ & 17.00 & 0.9 & 16.1 & 259.21 \\
\hline $1998 / 2008$ & 13.60 & 0.2 & 13.40 & 179.56 \\
\hline $1999 / 2009$ & 13.30 & 0.17 & 13.13 & 172.40 \\
\hline $2000 / 2010$ & 8.80 & 0.14 & 8.66 & 74.99 \\
\hline $2001 / 2011$ & 6.60 & 0.16 & 6.44 & 41.47 \\
\hline
\end{tabular}

Source: Researcher Computation from CBN Statistical Bulletin (2012)

From the table 2 above, the data were generated from the commercial bank loans to SMEs as a percentage of total credit from 1991-2012 (as obtain in column four of table 1) which were used in calculating the paired sampled t-test. X in table 2 represents percentage of loans to SMEs from 1991-2002 while Y represents percentage of loans to SMEs from 2001-2012 while d is the difference between $\mathrm{X}$ and $\mathrm{Y}$. the formula was then applied to compute the value of $t$ and then compare it with the critical value at 5\% significant level.

Nigerian Government over the years observed a decline in the ratio of loans by commercial banks to SMEs, to save this scenario SMEEIS was introduce in year 2001 to ensure a significant improvement in the ratio of loans to SMEs. This would have been so if the values of $d$ in (table 2) above were predominantly negative if not all. The $t$ in the end would have been a negative figure greater than the critical value. Computed value of $t=2.959$ and the critical value is 2.365 at 0.05 significance level and degree of freedom $\mathrm{df}=7$.

With this computation we obtained a positive value of computed $t$ which shows there was no significant improvement in loans to SMEs even after SMEEIS was introduced. The result of insignificance was due to the fact that SMEEIS did not create a significant impact on the financing of SMEs. We therefore accept the null hypothesis that Commercial banks loans granted to SMEs have no any significant impact on their development in Nigeria before and after SMEEIS introduction.

\subsection{Discussion of Result}

SMEs by their nature finds it difficult to raise finance internally, this necessitated for them to look for finance externally especially bank loans. It is clearly seen in table 2 that commercial banks loans to SMEs as a percentage to their total credit has been on the decrease from 1991-2000. To improve the scenario, SMEEIS was introduced in 2001 but SMEEIS could not meet the objectives for which it was established as can be seen in the ratio of loans as percentage of total credit of commercial banks granted to SMEs in year 2001 as $6.6 \%$ in table 2. The ratio of loans continues rises in 2002 and falls in 2003 again. However, the stringent conditions for accessing funds under the scheme by SMEs, reluctant of some commercial banks to contribute to the scheme in Nigeria and financial mismanagement by the benefiting SMEs and the administrators of loans also contribute to the failure of SMEEIS. Commercial banks in Nigeria only lends to enterprises that have high potential to repay loans, the genesis of this decrease in banking sector overall credit to SMEs in Nigeria started when 20\% of commercial banks profit before tax mandatory credit allocations to SMEs was abolished in 1996, therefore without mandatory regulations by government commercial banks cannot actively support SMEs in terms of financing. This is at variance with social contract theory which maintains that companies or rather commercial banks should lend a support to all stakeholders including entrepreneurs in the society. Based on these analyses, 
the researcher finds that commercial banks loans have not made significant improvements in helping SMEs in terms of loans granted to them even with the so- called small and medium enterprises equity investment scheme (SMEEIS).

\subsection{Findings of the Research}

Based on the analysis made in the preceding section, this study hereby reveals the following findings:

- Weak performance of financing of SMEs by commercial banks in Nigeria even with the SMEEIS put in place.

- Decline in the ratio of commercial banks loans to SMEs as a percentage of their total credit from year 1991-2012 except the recorded highest increment in year 2004 because banks feel reluctant to contribute to SMEEIS since there is no legal framework backing the scheme like the mandatory 20 percent credit to SMEs before 1996 abolition.

- Stringent conditions of accessing SMEEIS funds may prevent SMEs from accessing and benefitting from the scheme.

\section{Conclusion}

The purpose of this study was to evaluate the role of commercial banks in financing SMEs in Nigeria. Over the years, considerable attention has been paid to the issue of financing SMEs in Nigeria, because there is absolutely no doubt that small and medium scale enterprises contribute tremendously to the nation's economic growth and development, but harnessing the economic potentials of SMEs in Nigeria is still a mirage because SME finds it difficult to access funds especially from commercial banks despite the SMEEIS schemes initiated and funded by the commercial banks and other incentives put in place by government to support prospective SMEs operators in Nigeria to have easy access to funds set aside for SMEs development. However, this study has shown that SMEs in Nigeria have insufficient access to finance from financial institutions, and as a result, rely more and more on their own savings or friends' and relatives' savings among others for their investment capital. Commercial Banks which are suppose to provide loans and implement SMEEIS requires collaterals which most SMEs cannot provide. SMEs are also discouraged by continuous increase in lending rate or interest rate. The CBN in its own way also try to aid the financing of SMEs through several approaches such as use of monetary and policy guidelines to channel credit as well as operation of loan guarantee scheme and gingering of SMEEIS by commercial banks among others. However, the current modus operandi of the SMEEIS is in a number of ways, not exactly according to the basic understanding of the public and the original conception of CBN. though these efforts have attained varying levels of success and have actually moved the SME sub-sector forward. Hence, much still needs to be done by all the stakeholders in the sub-sector. This hopefully would minimize the constraints to accessing institutional credit by the SMEs, while ensuring that identified bottlenecks to the efforts are corrected. The study also explore financing problems from both commercial banks and SMEs side and the solutions to financing problems to small and medium scale enterprises were enumerated. Efforts were also made to identify several sources of finance available to small and medium scale enterprises, Issues raised by both commercial banks and the SMEs were analyzed and discussed. If SMEs mainly depends on bank loans, and the bank loans are not made available for common SMEs in the country, the situation could be disastrous and this will impact negatively on the economy of the nation and hinder the achievement of vision 20-20-20 which Nigerian government is clamouring to achieve. 


\section{Recommendation}

If the following policy recommendations are given serious attention by both the key players' i.e. the government, commercial banks and the SMEs themselves, financing the SMEs by commercial banks will be made a lot easier, more effective and the impact will be felt towards the growth and development of small and medium scale enterprises vis-à-vis the economic growth and sustainable development of Nigeria:

- If Nigeria is to achieve adequate and sustainable financing for small and medium scale enterprises by commercial banks and other development banks and credit agencies established. Commercial banks should stop exhibiting risk-averse behavior in respect of granting loans to small and medium scale enterprises.

- The Central bank of Nigeria should reduce the lending rate or interest rate in respect of loans to SMEs since high lending rate discourages SMEs from borrowing. For instance, presently lending rate in commercial banks is $24 \%$ and this has a negative impact on the ability of small and medium scale enterprises to obtain credit from the banks. The lending rate to SMEs should be single digit.

- The Central Bank of Nigeria (CBN) and other financial institutions should embark on extensive SMEs enlightenment with the provisions of credit requirements by commercial banks through efficient training and counseling of the small and medium scale entrepreneurs to enable them access credit facilities with ease.

- SMEEIS contribution by commercial banks should be increased to $25 \%$ of their profit before tax. This is borne out of the fact that their capital base when banks were contributing $10 \%$ was not up to twenty five billion naira.

- The government should established specialized bank to provide loans to SMEs. The Bank if established should provide loans and other financial support at the barest minimum interest rate. This is purposive so as to encourage the SMEs to patronize the institution.

- SMEs should not rely mainly for banks loans, they should consider all available financing options that would enable them expands their business.

- The government should provide adequate infrastructural facilities like electricity, roads and water supply for the SMEs and these no doubt will go a long way in reducing the production costs of SMEs. This will also encourage banks to fund the SMEs as their investment will be recouped.

- The banks should adopt relationship lending as a dominant bank rule in funding SMEs.This will mitigate the problem of weak asset based collateral. However, this can be more effective if the borrowers show some high level of responsibility, discipline and trustworthiness.

- The Nigerian populace should patronize made in Nigerian goods especially SMEs products so as to encourage the sub-sector to developed government should support SMEs by bulk purchasing their products and retailing them both for the domestic market and for exports.

- All administrative bottle necks which make funds inaccessible to small and medium scale

- Enterprises operators should be mitigated and therefore, the security situation of the country needs to be improved so as to make small and medium scale businesses doable in the country.

\section{References}

Aernold, H.B. (1998). "A Strategy for Asian Development", "Economic Development and Cultural Change Impact on Small And Medium Scale Enterprises.” Journal of finance review, vol. 5, No. 3. 
An Evaluation of the Role of Commercial Banks in Financing Small and Medium Enterprises (SMEs): Evidence from Nigeria

Agumagu, A.C. (2006). "Finance for Industry and Commerce", The Business of Banking, Lectures and Proceedings at the 26th International Banking Summer School, Delivered in Oxford.

Akabueze, B. (2002). "Prospectus on Nigeria SMEs under the Small and Medium Industries Investment Scheme" (SMIEIS). Availablewww.nigeriabusinessinfor.com/nigeriansmes2000.htm.

Aladekomo, F.O. (2003). "The Small and Medium Enterprises" (SME) Landscape: Environment, Government Policies, programmes, and Institutional Support", A paper delivered at a workshop on "Strategies for Operationalizing Small and Medium Industries Equity Investment Scheme (SMIES) in Nigeria" in year 2003, Lagos, Nigeria.

Anic, V. and Pauš, V. (1998). "The Croatian SME study" Best Practice In Financing SMEs In SECI And CEI Countries": Final Report of UN/ECE Expert Meeting on Best Practice in Financing SMEs, Geneva (Switzerland). Available at www.unitednations.org.

Aruwa, S.A.S. (2004). "Financing Options For Small And Medium-Scale Enterprises In Nigeriae, The Nigerian Journal of Accounting and Research, Department of Accounting, Ahmadu Bello University, Zaria. Vol.1, No.2.

Ayesha, N.B. (2007). "Policies For Financing Of Small-Scale Industries: Kenyan Experience", Small-Scale Industries Promotion in Developing Countries.

Ayozie, D.O, And Latinwo, H.K (2010). "Entrepreneurship Developments And Small Scale Industry Contribution To Nigerian National Development"- A Marketing Interface, Information Management And Business Review. Vol. 1, No. 2.

Berger, A.N. And Udell, G.F. (2004). "A More Complete Conceptual Framework For SME Finance. A Paper Presented at The World Bank Conference On Small And Medium Enterprises: Overcoming Growth Constraints World Bank.

Central Bank Of Nigeria (2012). Statistical Bulletin. Abuja : CBN Available At www.cenbank.org.ng

Central Bank of Nigeria (2006). Small and Medium Enterprises Equity Investment Scheme (SMEEIS) (An initiative Bankers Committee): Revised Guidelines for Operative of the Scheme Abuja.

Demirguc-Kunt, Maksimpvic, Beck And Laeven (2006), "Problems Of Small Businesses And Why They Fail In Developing Countries.” Journal of General Studies, Bayero University, Kano.

Ebube, D. (2011). "Nigerian Commercial Banks And Problems Of Financing Small And Medium Scale Enterprises In Nigeria. Journal of Social and Management Review ,Vol. 5, No. 1.

Finlayson, A.B (2003. "Small and Medium Scale Enterprises and Economic Growth: An Assessment of Smes Impact on the Economy of Some Selected ASEAN Countries" Journal Of Management Review. Vol. 2, no. 5 .

Garba U.H (2005). "The Role of Small and Medium Scale Industries in Growth and Development of modern economy." Journal of Business Management, Vol. 2, No. 3.

Global Enterpreneurship Monitor (GEM) Survey -2008

Hossain, N. (1998). "Constraints to SME development in Bangladesh, job opportunities and business support" (JOBS) program.

World Economic Assessment, Coordination and Integration WEACI (2002).

Iorpev, L. (2012) "Does Bank Size Matter To Small And Medium Scale Enterprises (Smes) Financing In Nigeria?" International Journal of Business and Management Tomorrow. Vol. 2, No. 3 
An Evaluation of the Role of Commercial Banks in Financing Small and Medium Enterprises (SMEs): Evidence from Nigeria

Inang, E.E. and G.E. Ukpong (1992). "A review of small-scale enterprises credit delivery strategies in Nigeria." Economic and Financial Review. CBN, Vol.30 No.4.

Kadiri, I.B (2012). "Developing small and medium enterprises in Nigeria: problems and prospects" journal of advances in management, Vol. 7 No. 2

Mambula, C. (2002). "Perceptions of SME growth constraints in Nigeria." Journal of Small Business Management, Vol. 40, No. 16

National Council On Industries 2001-2006 (revised operational guidelines)

Nnanna, O.J. (2001). "Financing small business under the new CBN directive and its likely impact on industrial growth of the Nigerian economy." CBN Bulletin, July/ September Vol. 25 No. 3.

ogujiuba, et al (2004). "Credit availability to small and medium scale enterprises in Nigeria: importance of new capital base for banks-background and issues." AIAE working paper.

Olorunshola, J.A. (2003). "Problems and prospects of SME industries in Nigeria." A paper presented at CBN seminar on SMIEIS.

Philip, J. (1989). “The Benefit of Firm Creditors Relationship: Evidence from Small Business Data.” Journal of Finance, Vol. 49. No. 2.

Sifiriyu, A.M. and Njogo, B.O. (2012). "Impact of SME in the generation of employment in Lagos state." Kuwait chapter of Arabian journal of business and management review. Vol. 1, No. 11.

Salami, A.T (2003). "Guidelines and Stakeholders Responsibilities in SMIEIS.” A Paper Presented At Central Bank Of Nigeria (Cbn) Seminar Smeeis. Lagos.

Terungwa, A. (2011). "Corporate social responsibility in Nigerian banking system: the development of small and medium scale enterprises." World Journal of Social Sciences, Vol. 1. No. 5.

Udechukwu N.F. (2003). "Survey of small and medium scale industries and their potentials in Nigeria." A paper presented at CBN seminar on SMIEIS.

Valverde et al, (2005). "Bank market power and SME financing constraints." A paper presented at the I workshop on economics, Granada.

Wattanapruttipaisan, T. (2003). "Four proposals for improved financing of SME development in ASEAN. Asian Development Review. Vol. 20, No. 2.

World Bank (1995). Nigeria: "A diagnostic Review of the Small and Medium Scale Enterprise Sector." (Interim Report)

World Bank (2000). World Bank Survey on SME Financing In Developing Countries.

World Bank (2001). World Bank Survey 2001.

World Bank (2008). World Bank Survey on Sustainable Development.

World Bank (2011). World Bank Survey 2011.

\section{Copyrights}

Copyright for this article is retained by the author(s), with first publication rights granted to the journal. 